\title{
Effects of acute leg ischemia during cycling on oxygen and carbon dioxide stores
}

\author{
Jack A. Loeppky, PhD; ${ }^{\mathbf{*}^{*}}$ Burke Gurney, PhD; ${ }^{2}$ Milton V. Icenogle, $\mathrm{MD}^{\mathbf{3}}$ \\ ${ }^{1}$ Research Service, Department of Veterans Affairs Medical Center (VAMC), Albuquerque, NM; ${ }^{2}$ Department of \\ Orthopaedics and Division of Physical Therapy, University of New Mexico Health Sciences Center, Albuquerque, NM; \\ ${ }^{3}$ Cardiology Section, VAMC, Albuquerque, NM
}

\begin{abstract}
This study estimated changes in whole body oxygen stores $\left(\mathrm{O}_{2} \mathrm{~s}\right)$ and carbon dioxide stores $\left(\mathrm{CO}_{2} \mathrm{~s}\right)$ during steady state exercise with leg ischemia induced by leg cuff inflation. Six physically fit subjects performed $75 \mathrm{~W}$ steady state exercise for $15 \mathrm{~min}$ on a cycle ergometer. After $5 \mathrm{~min}$ of exercise, cuffs on the upper and lower legs were inflated to $140 \mathrm{mmHg}$. Cuffs were deflated after $5 \mathrm{~min}$ and exercise continued for another 5 min. $\mathrm{O}_{2}$ uptake $\left(\dot{\mathrm{VO}}_{2}\right)$ and $\mathrm{CO}_{2}$ output $\left(\dot{\mathrm{V} C \mathrm{C}_{2}}\right)$ significantly increased during the first $30 \mathrm{~s}$ after inflation, significantly decreased between 60 and $90 \mathrm{~s}$, and then rose linearly until deflation. $\dot{\mathrm{V}}_{2}$ and $\dot{\mathrm{V}} \mathrm{CO}_{2}$ significantly increased further after cuff deflation, peaking between 30 and $60 \mathrm{~s}$ and then returned to near baseline exercise levels. Modelestimated changes in total $\mathrm{O}_{2} \mathrm{~S}$ and $\mathrm{CO}_{2} \mathrm{~S}$ were compared with time-integrated store changes from $\dot{\mathrm{VO}}_{2}$ and $\dot{\mathrm{V}} \mathrm{CO}_{2}$. During 5 min after cuff deflation, $\dot{\mathrm{VO}}_{2}$ and $\dot{\mathrm{V}} \mathrm{CO}_{2}$ exceeded the model-estimated change in stores by 273 and $697 \mathrm{~mL}$, respectively. These results reflect the $\mathrm{O}_{2}$ cost repayment of the anaerobic component and lactate buffering to neutralize circulating metabolites caused by the preceding ischemia.
\end{abstract}

Key words: anaerobic exercise, bicarbonate buffering, carbon dioxide stores, ergoreflex, ischemia, lactate, oxygen deficit, oxygen stores, rehabilitation, ventilation/perfusion ratio, ventilation response.

\section{INTRODUCTION}

Progressive physical deconditioning is common in patients with chronic diseases, such as congestive heart failure and chronic obstructive pulmonary disease. One limitation these patients face is an inability to exercise with sufficient intensity to provide adequate training stimuli. However, regional training of muscles without taxing the central circulation can improve whole-body exercise capacity in these patients [1]. An unusual potential tool to facilitate regional muscle rehabilitation is exercise training during reduced limb blood flow [2-3]. Such "ischemic

Abbreviations: $\mathrm{ADS}=$ anatomical dead space $(\mathrm{mL}), \mathrm{BE}=$ base excess (measure of whole blood buffer base $[\mathrm{mmol} / \mathrm{L}]$ ), $\mathrm{CO}_{2}=$ carbon dioxide, $\mathrm{CO}_{2} \mathrm{~S}=\mathrm{CO}_{2}$ stores $(\mathrm{mL}), \mathrm{f}=$ breathing frequency (breaths/min), $\mathrm{FIO}_{2}=$ fraction of inspired oxygen, $\mathrm{H}^{+}=$hydrogen ion concentration ( $\mathrm{nmol} / \mathrm{L}$ ), $\mathrm{Hb}=$ hemoglobin concentration (g\%), $\mathrm{HCO}_{3}{ }^{-}=$bicarbonate concentration $(\mathrm{mmol} / \mathrm{L}), \mathrm{O}_{2}=$ oxygen, $\mathrm{O}_{2} \mathrm{~S}=\mathrm{O}_{2}$ stores $(\mathrm{mL}), \mathrm{PACO}_{2}=$ partial pressure of alveolar $\mathrm{CO}_{2}(\mathrm{mmHg}), \mathrm{PAO}_{2}=$ partial pressure of alveolar $\mathrm{O}_{2}(\mathrm{mmHg}), \mathrm{P}_{\mathrm{B}}=$ barometric pressure, $\mathrm{PCO}_{2}=$ partial pressure of $\mathrm{CO}_{2}(\mathrm{mmHg}), \mathrm{pHa}=$ arterial $\mathrm{pH}, \mathrm{PO}_{2}=$ partial pressure of $\mathrm{O}_{2}(\mathrm{mmHg}), \dot{\mathrm{Q}}=$ cardiac output $(\mathrm{L} / \mathrm{min}), \mathrm{RER}=$ respiratory exchange ratio $\left(\mathrm{CO}_{2}\right.$ output $/ \mathrm{O}_{2}$ uptake), $\dot{\mathrm{V}}_{\mathrm{A}}=$ alveolar ventilation ([L/min] body temperature, ambient pressure, saturated), $\dot{\mathrm{V}} \mathrm{CO}_{2}=\mathrm{CO}_{2}$ output $([\mathrm{mL} / \mathrm{min}]$ standard temperature and pressure, dry), $\dot{\mathrm{V}}_{\mathrm{E}}=$ pulmonary ventilation $([\mathrm{L} / \mathrm{min}]$ body temperature, ambient pressure, saturated), $\dot{\mathrm{VO}}_{2}=\mathrm{O}_{2}$ uptake ([mL/min] standard temperature and pressure, dry), $\dot{\mathrm{VO}}_{2 \text { max }}=$ maximal $\dot{\mathrm{VO}}_{2}$.

*Address all correspondence to Jack A. Loeppky, PhD; Research Service, VAMC, 1501 San Pedro Dr SE, Albuquerque, NM 87108; 250-489-4597; fax: 250-489-8256. Email: loeppkyi@telus.net or loeppky@unm.edu DOI: 10.1682/JRRD.2007.11.0198 
limb training" with limb pressure cuffs has improved limb strength and exercise endurance in physically fit subjects [4-5], diminished postoperative disuse atrophy of knee extensors [6], and induced favorable biochemical and structural changes in muscles [7-8]. Ischemic limb training with low-intensity exercise in patients with congestive heart failure has also reduced exertional dyspnea [9]. We recently demonstrated that leg-extension exercise endurance was enhanced with a 6-week training program of very light leg-extension exercise with ischemia induced by thigh cuff inflation [10].

Superimposing ischemia on exercising limbs provokes the muscle metaboreflex, whereby pulmonary ventilation $\left(\dot{\mathrm{V}}_{\mathrm{E}}\right)$ and systemic blood pressure are elevated by a chemoreflex stimulated by buildup of metabolic byproducts in the ischemic limbs; the most likely candidate is hydrogen ion concentration $\left(\mathrm{H}^{+}\right)$[11]. The oxygen $\left(\mathrm{O}_{2}\right)$ stores $\left(\mathrm{O}_{2} \mathrm{~s}\right)$ and carbon dioxide $\left(\mathrm{CO}_{2}\right)$ stores $\left(\mathrm{CO}_{2} \mathrm{~s}\right)$ in the region where blood flow is occluded, as well as in the whole body, will be affected during this ischemia and after circulation is restored as a result of ventilatory, blood flow, and biochemical perturbations. The magnitude and time course of these gas store changes will affect regional and whole-body acid-base status, will cause secondary ventilatory and gas exchange fluctuations during and after exercise, and may induce transient hypoxemia and hypercapnia, such as noted following passive changes in posture [12].

Although rapid transient changes in $\mathrm{O}_{2} \mathrm{~S}$ and $\mathrm{CO}_{2} \mathrm{~S}$ during exercise workload transitions have been studied and quantified [13], gas store changes induced by limb ischemia have received little attention. Specifically, the quantitative relationship is not well defined between $\mathrm{O}_{2}$ repayment and $\mathrm{CO}_{2}$ elimination after exercise requiring energy partially derived from anaerobic sources [14] and these measurements with the anaerobic component artificially superimposed have not been reported. Therefore, this study was an initial attempt to estimate the time course and magnitude of changes in $\mathrm{O}_{2} \mathrm{~S}$ and $\mathrm{CO}_{2} \mathrm{~S}$ during and after acute, temporary ischemia of the legs applied by cuff inflation during steady state exercise on a cycle ergometer.

\section{METHODS}

\section{Subjects}

Five men and one woman volunteered as subjects. Informed consent was obtained from each person, as approved by the University of New Mexico Human Research Review Committee. All were physically fit and regularly taking part in physical recreation and fitness activities, including jogging and cycling. Their ages ranged from 24 to $62 \mathrm{yr}$, with a mean body weight and body mass index of $82.5 \mathrm{~kg}$ and $25.0 \mathrm{~kg} / \mathrm{m}^{2}$, respectively. Their maximal $\mathrm{O}_{2}$ uptake $\left(\dot{\mathrm{VO}}_{2 \max }\right)$ averaged $48 \mathrm{~mL} \cdot \mathrm{min}^{-1} \cdot \mathrm{kg}^{-1}$ (range: 42-56). The $\mathrm{O}_{2}$ uptake $\left(\mathrm{V}_{2}\right)$ during exercise before ischemia (baseline) averaged 35.7 percent (range: $30 \%-42 \%$, standard error of the mean $=1.7 \%$ ) of the subjects' $\dot{\mathrm{V}} \mathrm{O}_{2 \max }$. This percentage was not related to age $(r=-0.22)$.

\section{Ergometer Exercise and Inflation Cuffs}

We placed cuffs on each upper thigh (SC-17, Hokanson Co; Bellevue, Washington) and each lower leg (SC22) using adhesive tape to keep them in position during exercise. Lower leg cuffs were used to minimize trapping of blood and to enhance ischemia of the calf muscles. Cuffs were inflated to $140 \mathrm{mmHg}$ during exercise. This cuff pressure, slightly exceeding systolic pressure, was chosen after preliminary trials indicated that discomfort at this pressure could be tolerated and gas exchange transients stabilized in about 5 min at the chosen workload. Although the blood pressure response of each subject to the inflation pressure varied, we maintained the pressure at the same level for all to reduce variations in blood "pooling" and thereby reduce variability in the measured responses. Resting measurements were made for $5 \mathrm{~min}$ while subjects sat on the ergometer before and after exercise. Subjects cycled for $15 \mathrm{~min}$ at $75 \mathrm{~W}$ on an electrically load-controlled Bosch ergometer (model ERG 551; Munich, Germany) at 50 to $60 \mathrm{rpm}$. After $5 \mathrm{~min}$, the four cuffs were simultaneously inflated over a $\approx 10$ s period from a gas cylinder pressure source. Cuff pressure was maintained for $5 \mathrm{~min}$ and then deflated rapidly in $3 \mathrm{~s}$, with exercise continuing for another $5 \mathrm{~min}$.

\section{Measurements and Calculations}

We measured gas exchange at the mouth while subjects sat on the ergometer at rest, during exercise, and at rest after exercise, using a TrueMax 2400 breath-by-breath automated system (Parvomedics, Inc; Sandy, Utah) with incorporated software and model 2700 Rudolph breathing valve and mouthpiece (Hans Rudolph, Inc; Shawnee, Kansas). The measurements included $\mathrm{VO}_{2}, \mathrm{CO}_{2}$ output $\left.(\dot{\mathrm{V} C O})_{2}\right), \dot{\mathrm{V}}_{\mathrm{E}}$, calculated respiratory exchange ratio (RER), and $\dot{\mathrm{V}}_{\mathrm{E}} / \dot{\mathrm{V}} \mathrm{CO}_{2}$ as an index of ventilatory drive. Alveolar ventilation $\left(\dot{\mathrm{V}}_{\mathrm{A}}\right)$ was calculated from anatomical 
dead space (ADS) taken as apparatus dead space + milliliter = body weight in pounds [15] and breathing frequency (f) as $\dot{\mathrm{V}}_{\mathrm{A}}=\dot{\mathrm{V}}_{\mathrm{E}}-\mathrm{f} \times$ ADS. Experiments were conducted at an average barometric pressure $\left(\mathrm{P}_{\mathrm{B}}\right)$ of $631 \mathrm{mmHg}$ (range: 630-635 mmHg) and ambient fraction of inspired $\mathrm{O}_{2}$ $\left(\mathrm{FIO}_{2}\right)$ of 0.2094 . Partial pressure of $\mathrm{CO}_{2}\left(\mathrm{PCO}_{2}\right)$ in alveoli $\left(\mathrm{PACO}_{2}\right)$ and partial pressure of $\mathrm{O}_{2}\left(\mathrm{PO}_{2}\right)$ in alveoli $\left(\mathrm{PAO}_{2}\right)$ were calculated from alveolar gas equations [16]:

$$
\mathrm{PACO}_{2}=\left(\dot{\mathrm{V} C O}{ }_{2} \times 0.863\right) / \dot{\mathrm{V}}_{\mathrm{A}}
$$

and

'AO ${ }_{2}=\left(\mathrm{P}_{\mathrm{B}} \angle 47.1\right) \mathrm{FIO}_{2} \angle \mathrm{PACO}_{2}\left[\mathrm{FIO}_{2}+\left(1 \angle \mathrm{FIO}_{2}\right) / \mathrm{RER}\right]$.

We averaged breath-by-breath measurements continuously over $30 \mathrm{~s}$ intervals for each subject throughout exercise and the pre- and postexercise rest periods. We then averaged these values for the six subjects to obtain representative temporal patterns for analysis.

Average changes in $\mathrm{O}_{2} \mathrm{~S}$ and $\mathrm{CO}_{2} \mathrm{~S}$ were calculated from differences between measured and predicted gas exchange time courses integrated over time. We based predicted values on baseline gas exchange measurements during the 5th min, assuming these represented steady state values required by the workload, and an increase during ischemia based on assumptions given in the subsequent section for predicted gas exchange. An increase in $\mathrm{O}_{2} \mathrm{~S}$ was indicated when measured $\dot{\mathrm{VO}}_{2}$ is greater than predicted $\dot{\mathrm{V}} \mathrm{O}_{2}$ over time, and a decrease in $\mathrm{CO}_{2} \mathrm{~S}$ was indicated when measured $\dot{\mathrm{V} C O}{ }_{2}$ is greater than predicted $\dot{\mathrm{V}} \mathrm{CO}_{2}$ and vice versa. Differences in these gas store changes during and after blood flow restriction were attributed to the ischemia. In addition, we obtained total body gas stores present during baseline, 5th min during cuff inflation, and 5th min after cuff deflation from a model using gas exchange, blood flow, and blood volume values. We also used differences between these modeled total store values and the time-integrated measured values of changes in $\mathrm{O}_{2} \mathrm{~S}$ and $\mathrm{CO}_{2} \mathrm{~s}$ to extract effects of leg ischemia.

\section{Predicted Gas Exchange}

During cuff inflation, we assumed the predicted time course for $\dot{\mathrm{V}} \mathrm{O}_{2}$ would increase linearly during the 6th through 10th min from the steady state exercise value at 5 min because of-

1. A gradual loss of mechanical efficiency by increasing recruitment of ancillary muscles of the hip, torso, and arms to maintain leg work as fatigue increased.
2. Increased $\mathrm{O}_{2}$ cost of ventilation stimulated by the metaboreflex, which may account for as much as onethird of the observed $\dot{\mathrm{VO}}_{2}$ rise [17-18].

3. The partial restoration of curtailed leg circulation by the reflex rise in blood pressure that would enhance $\mathrm{O}_{2}$ delivery to the legs despite restricted blood flow during cuff inflation.

4. The subjects' subjective reports that the last minute of exercise seemed less stressful than the previous minutes, indicating that the anaerobic component of the energy supply had stabilized.

During the 5 min following cuff deflation, $\dot{\mathrm{VO}}_{2}$ was assumed to decline exponentially to the baseline exercise value by $15 \mathrm{~min}$ because the factors just listed were removed by cuff deflation and the elevated $\dot{\mathrm{V}}_{2}$ was expected to return similarly to that following the removal of an additional acute exercise workload. The predicted $\dot{\mathrm{V}} \mathrm{CO}_{2}$ was similarly assumed to increase linearly from baseline to $10 \mathrm{~min}$, but to a value calculated as measured $\dot{\mathrm{V}} \mathrm{O}_{2} \times$ measured baseline RER before cuff inflation (for correcting the elevated $\dot{\mathrm{V} C O} \mathrm{O}_{2}$ from the increase in $\dot{\mathrm{V}}_{\mathrm{E}}$ resulting from the metaboreflex), and then decline exponentially to the baseline value by $15 \mathrm{~min}$.

\section{Total Gas Stores Model with Blood Flow and Volume Redistribution}

Computations and assumptions are shown in the following list for compartmental and total whole body $\mathrm{O}_{2} \mathrm{~S}$ and $\mathrm{CO}_{2} \mathrm{~S}$ during exercise at three exercise conditions $\mathrm{A}$, $\mathrm{B}$, and $\mathrm{C}$ : $\mathrm{A}=$ baseline, 5th min before cuff inflation; $\mathrm{B}=$ 5th min of cuff inflation; and $\mathrm{C}=5$ th min after cuff deflation. Arterial and mixed venous blood $\mathrm{O}_{2}$ and $\mathrm{CO}_{2}$ contents and mixed venous $\mathrm{PO}_{2}$ and $\mathrm{PCO}_{2}$ were calculated from a computer model integrating gas exchange and blood flow values [19-20].

- Blood volume.

- Total $=71.5 \mathrm{~mL} / \mathrm{kg}$ body weight $=5,900 \mathrm{~mL}$.

- Venous compartment for exercise conditions A and $\mathrm{C}=$ total $\times 0.8=4,720 \mathrm{~mL}$.

- Arterial compartment for exercise conditions A and $\mathrm{C}=$ total $\times 0.2=1,180 \mathrm{~mL}$.

- During condition B, a $300 \mathrm{~mL}$ blood volume shift from the venous to arterial compartment was predicted based on transient increases in measured $\dot{\mathrm{VO}}_{2}$ and a $\dot{\mathrm{V} C O}{ }_{2}$ from 30 to $60 \mathrm{~s}$ after cuff deflation.

- Lung: $\mathrm{O}_{2}$ and $\mathrm{CO}_{2}$ were calculated from $\mathrm{PAO}_{2}$ and $\mathrm{PACO}_{2}$ and an assumed functional residual capacity of $4.0 \mathrm{~L}$. 
- Arterial $\mathrm{O}_{2}$ : Content based on $\mathrm{Hb}$ (hemoglobin concentration) $=15 \mathrm{~g} \%$, arterial $\mathrm{PO}_{2}=\mathrm{PAO}_{2}$, saturation = standard dissociation curve [21] at $\mathrm{pHa}$ (arterial $\mathrm{pH}$, the negative $\log$ of $\mathrm{H}^{+}$in arterial blood) calculated to maintain whole blood base excess (BE) equal to baseline [22], where a pHa value of 7.420 was assumed.

- Venous $\mathrm{O}_{2}$ : Content from Fick equation with arterial content and measured $\mathrm{VO}_{2}$ at exercise conditions $\mathrm{A}$, $\mathrm{B}$, and $\mathrm{C}$ and cardiac output $(\dot{\mathrm{Q}})=15 \mathrm{~L} / \mathrm{min}$ at conditions $\mathrm{A}$ and $\mathrm{C}$, with $1 \mathrm{~L} /$ min reduction during condition $\mathrm{B}$, based on observations during cuff-induced ischemia by Asmussen and Nielsen [23].

- Tissue $\mathrm{O}_{2}$.

- $\mathrm{PO}_{2}$ from venous content and saturation from standard curve.

- $\mathrm{PO}_{2} \times$ body weight $(82.5 \mathrm{~kg}) \times 0.64 \times 0.024$ [24]

- Arterial $\mathrm{CO}_{2}$.

- Content based on arterial $\mathrm{PCO}_{2}=\mathrm{PACO}_{2}$.

- Content from $\mathrm{CO}_{2}$ dissociation curve at $\mathrm{Hb}$ and pHa [25].

- Venous $\mathrm{CO}_{2}$ : Content from Fick equation with arterial $\mathrm{CO}_{2}$ content and measured $\dot{\mathrm{V}} \mathrm{CO}_{2}$ and predicted $\dot{\mathrm{Q}}$ at exercise conditions $\mathrm{A}, \mathrm{B}$, and $\mathrm{C}$.

- Tissue $\mathrm{CO}_{2}$.

- $\mathrm{PCO}_{2}$ for venous content from $\mathrm{CO}_{2}$ dissociation curve.

- $\mathrm{PCO}_{2} \times$ body weight $\times 1.02$.

We obtained half-times for rest-to-exercise (“on”) responses and ("off") transitions from exponential fits to the 10 measured breath-by-breath intervals. We used paired $t$-tests to determine significance $(p<0.05)$ of selected individual transient changes over time and used least squares linear regressions to estimate the significance of relationships between selected variables.

\section{RESULTS}

The average $\dot{\mathrm{VO}}_{2}$ and $\dot{\mathrm{V}} \mathrm{CO}_{2}$ measurements during rest, exercise, and postexercise rest are shown in Figure 1. A plateau for both measurements was reached after $\approx 3 \mathrm{~min}$ of exercise, because the 5th min values were not significantly above the $3 \mathrm{~min}$ values $(p>0.13)$. Transient changes induced by ischemia and cuff deflation appeared to have stabilized by the end of exercise. The baseline mechanical efficiency at $75 \mathrm{~W}$ for a $\dot{\mathrm{VO}}_{2}$ of $1,410 \mathrm{~mL} / \mathrm{min}$ (minus the resting $\mathrm{VO}_{2}$ of $335 \mathrm{~mL} / \mathrm{min}$ ) was 20.0 percent,

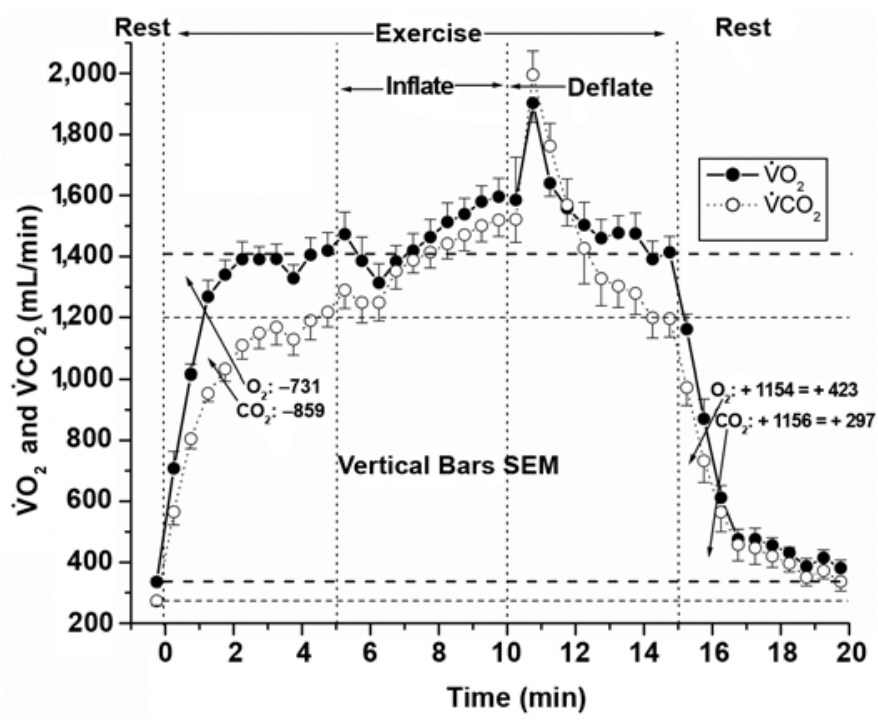

Figure 1.

$\dot{\mathrm{V}} \mathrm{O}_{2}$ and $\dot{\mathrm{V}} \mathrm{CO}_{2}$ during rest, 15 min of cycle ergometer exercise at $75 \mathrm{~W}$, and $5 \mathrm{~min}$ postexercise rest. Each point is an average of $30 \mathrm{~s}$ values for six subjects. Values (milliliters) are shown for total $5 \mathrm{~min}$ exercise onset deficit and 5 min postexercise rest and sum for $\dot{\mathrm{V}}_{2}$ and $\dot{\mathrm{V}} \mathrm{CO}_{2}$. Postexercise excess is significantly greater than preexercise deficit for $\mathrm{O}_{2}(p=0.003)$ and $\mathrm{CO}_{2}(p=0.031) . \mathrm{CO}_{2}=$ carbon dioxide, $\mathrm{O}_{2}$ = oxygen, $\mathrm{SEM}=$ standard error of the mean, $\mathrm{V}_{\mathrm{CO}}=$ $\mathrm{CO}_{2}$ output, $\dot{\mathrm{V}} \mathrm{O}_{2}=\mathrm{O}_{2}$ uptake.

decreasing to 17.1 percent at $1,595 \mathrm{~mL} / \mathrm{min}$ by the end of inflation. During the $5 \mathrm{~min}$ postexercise rest period, the total excess $\dot{\mathrm{VO}}_{2}$ and $\dot{\mathrm{V}} \mathrm{CO}_{2}$ were both significantly larger than the $5 \mathrm{~min} \mathrm{VO}_{2}$ deficits following exercise onset. The averages of the corresponding changes in gas stores calculated from time-integrated values for measured and predicted $\dot{\mathrm{V}} \mathrm{O}_{2}$ and $\dot{\mathrm{V}} \mathrm{CO}_{2}$ are detailed in Figure 2.

\section{Oxygen}

Measured $\dot{\mathrm{VO}}_{2}$ increased significantly during the first $30 \mathrm{~s}$ after cuffs were inflated $(p=0.042)$ and then declined transiently, but significantly, at $6.5 \mathrm{~min}$ by $72 \mathrm{~mL} / \mathrm{min}(p=$ 0.049). $\mathrm{VO}_{2}$ then rose steadily until cuffs were deflated. The $\mathrm{O}_{2} \mathrm{~s}$ cumulative loss over 5 min of cuff inflation was $227 \mathrm{~mL}$ (Figure 2). $\dot{\mathrm{V}} \mathrm{O}_{2}$ peaked $45 \mathrm{~s}$ after cuff deflation, being $150 \mathrm{~mL}$ above adjacent measurements $(p=0.001)$. The 5 min postdeflation exercise $\dot{\mathrm{VO}}_{2}$ excess indicated that $\mathrm{O}_{2} \mathrm{~s}$ increased by $518 \mathrm{~mL}$.

\section{Carbon Dioxide}

Measured $\dot{\mathrm{V}} \mathrm{CO}_{2}$ during ischemia is related to similar circulatory and biochemical events affecting $\mathrm{VO}_{2}$ but is partially overridden by the large increase in $\dot{\mathrm{V}}_{\mathrm{E}}$ (Figure 3), 


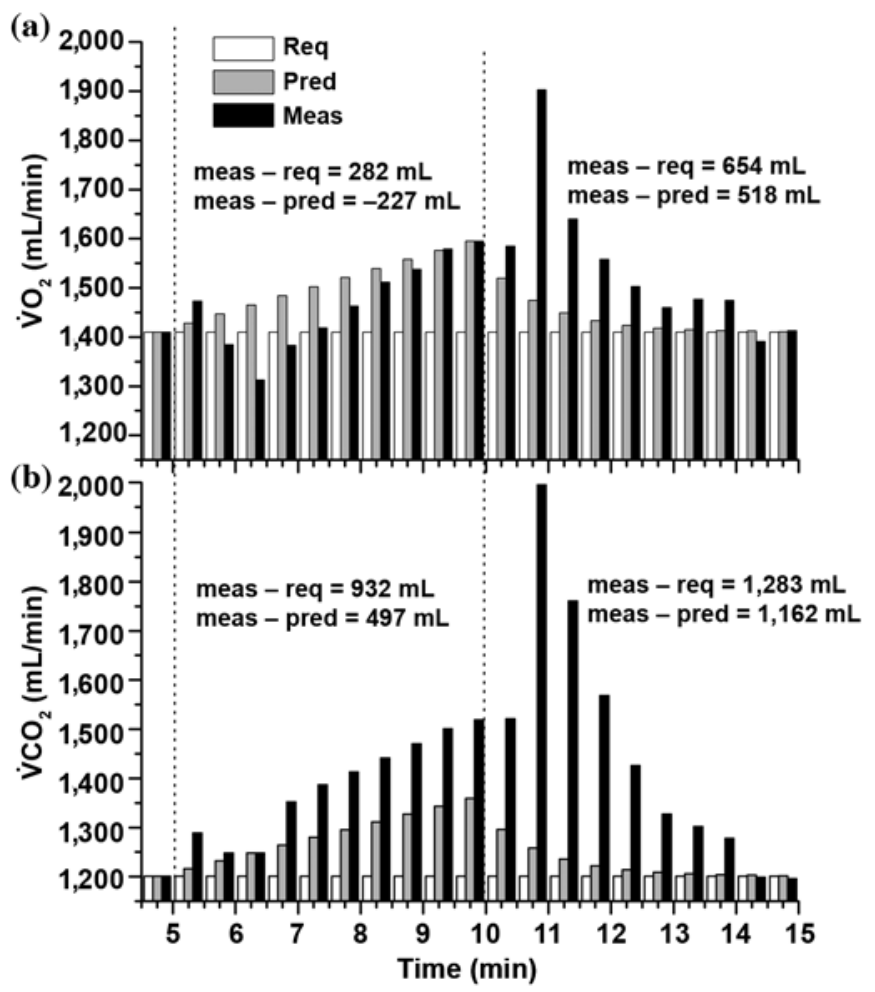

Figure 2.

Changes in gas stores represented by differences between measured (meas) (Figure 1) and predicted (pred) time course for (a) oxygen uptake $\left(\dot{\mathrm{VO}}_{2}\right)$ and (b) carbon dioxide output $\left(\dot{\mathrm{V}} \mathrm{CO}_{2}\right)$ during $5 \mathrm{~min}$ of cuff inflation and $5 \mathrm{~min}$ after cuff deflation at $10 \mathrm{~min}$. Values averaged for $30 \mathrm{~s}$. Predicted time course for $\dot{\mathrm{V}} \mathrm{O}_{2}$ and $\dot{\mathrm{V}} \mathrm{CO}_{2}$ is described in main text. Values for changes in stores (milliliters) are indicated for time-integrated totals over 5 min of inflation and 5 min after cuff deflation. req $=$ required.

because of the metaboreflex stimulation by leg ischemia. $\mathrm{CO}_{2} \mathrm{~s}$ decreased by $497 \mathrm{~mL}$ by the end of the $5 \mathrm{~min}$ inflation, as indicated in Figure 2. Similar to $\dot{\mathrm{VO}}_{2}$, the $\dot{\mathrm{V}} \mathrm{CO}_{2}$ peaked $45 \mathrm{~s}$ after cuff deflation, indicating an additional $180 \mathrm{~mL}$ loss in $\mathrm{CO}_{2} \mathrm{~s}$ above the adjacent measurements ( $p=0.002$ ), corresponding to the $150 \mathrm{~mL}$ of $\mathrm{O}_{2}$ taken up. The loss in $\mathrm{CO}_{2} \mathrm{~S}$ over $5 \mathrm{~min}$ after cuff deflation was $1,162 \mathrm{~mL}$, about double that of the $\mathrm{O}_{2} \mathrm{~s}$ gain $(518 \mathrm{~mL})$. Over the 10 min of exercise during cuff inflation and deflation, the total $\mathrm{O}_{2} \mathrm{~S}$ gain was $-227+518=291 \mathrm{~mL}$ and the total $\mathrm{CO}_{2}$ s loss was $497+1,162=1,659 \mathrm{~mL}$.

\section{Ventilation}

After exercise termination, the off-responses for $\dot{\mathrm{V}} \mathrm{CO}_{2}$ and $\dot{V}_{\mathrm{E}}$ (Figure 3) were similar to each other and their onresponses (36-39 s) but slower than the on-response for $\dot{\mathrm{V}} \mathrm{O}_{2}$. $\mathrm{VO}_{2}$ and $\dot{\mathrm{V}} \mathrm{CO}_{2}$ were slightly above baseline at the

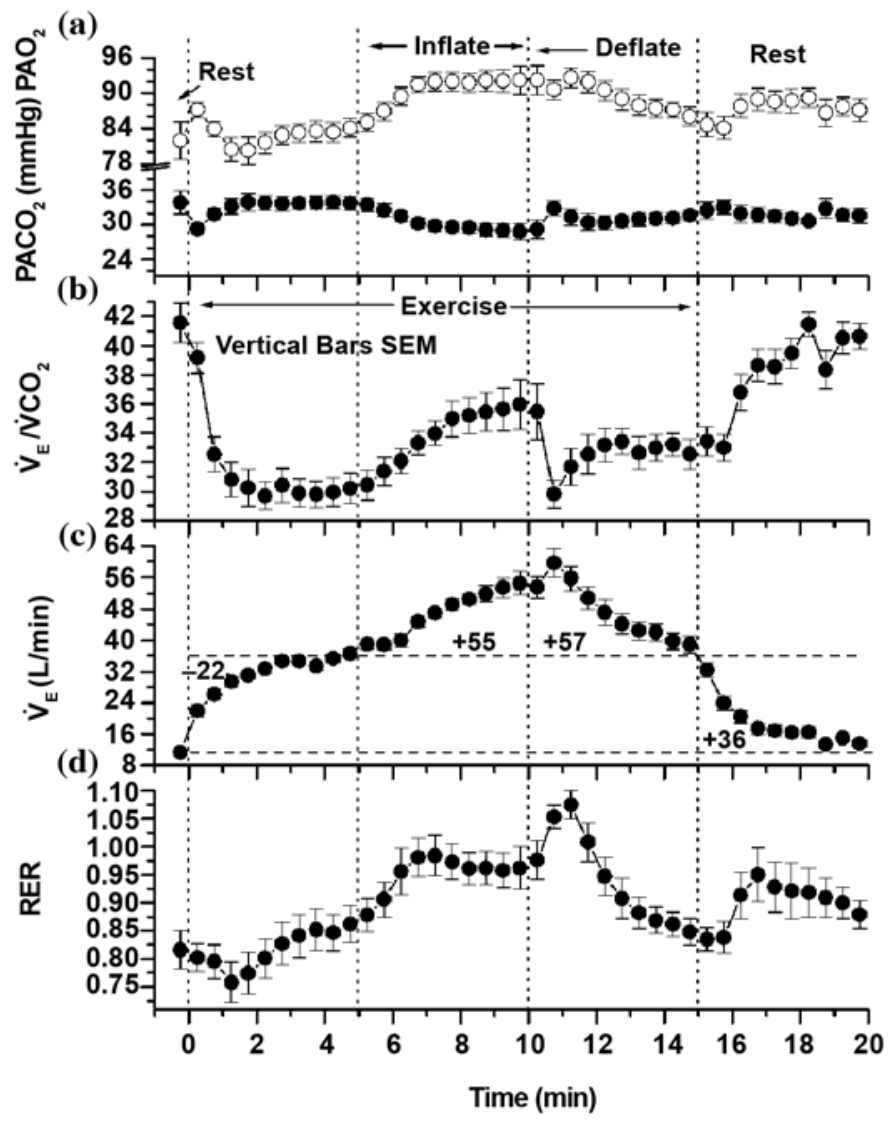

Figure 3.

Average values for six subjects for (a) alveolar gases; (b) $\dot{\mathrm{V}}_{\mathrm{E}} / \dot{\mathrm{V} C O}_{2}$; (c) $\dot{\mathrm{V}}_{\mathrm{E}}$; and (d) RER during rest, $15 \mathrm{~min}$ of exercise at $75 \mathrm{~W}$, and 5 min postexercise rest. Values (liters) are shown for cumulative timeintegrated $\dot{V}_{\mathrm{E}}$ deficit following exercise onset, cumulative excess during 5 min of cuff inflation, 5 min after cuff deflation, and 5 min of postexercise rest. Latter value is significantly greater than deficit at beginning of exercise. $\mathrm{PACO}_{2}=$ partial pressure of alveolar carbon dioxide, $\mathrm{PAO}_{2}$ = partial pressure of alveolar oxygen, $\mathrm{RER}=$ respiratory exchange ratio, SEM = standard error of the mean, $\dot{\mathrm{VCO}}_{2}=$ carbon dioxide output, $\dot{\mathrm{V}}_{\mathrm{E}}=$ pulmonary ventilation.

end of the $5 \mathrm{~min}$ postexercise rest period (Figure 1). The RER was significantly higher during the 5 th min postexercise rest compared with the preexercise rest because $\dot{\mathrm{V}} \mathrm{CO}_{2}$ was significantly higher (30\%) than $\dot{\mathrm{VO}}_{2}(18 \%)$, indicating a residual enhanced ventilatory drive.

\section{Whole Body $\mathrm{CO}_{2} \mathrm{~S}$}

By superimposing controlled hyperventilation, one can obtain estimates of whole-body $\mathrm{CO}_{2} \mathrm{~S}$ during exercise. From measurements in these "hyperventilation" experiments during ischemic exercise, the whole-body $\mathrm{CO}_{2}$ capacitance (dissociation curve) was $1.2 \mathrm{~L} \cdot \mathrm{mmHg}^{-1} \cdot \mathrm{kg}^{-1}$, as calculated 
from the excess of measured vs predicted $\dot{\mathrm{V}} \mathrm{CO}_{2}(497 \mathrm{~mL})$ (Figure 2) per change in $\mathrm{PACO}_{2}$ (5 mmHg) (Figure 3) per body weight (82.5 kg).

\section{Model of Total and Changing Gas Stores}

Table 1 shows the compartmental and total gas stores calculated for the three exercise conditions from the flow and volume redistribution model. Because lactate, bicarbonate concentration $\left(\mathrm{HCO}_{3}{ }^{-}\right)$, and $\mathrm{BE}$ changes are linearly related [22], we incorporated a decrease in whole blood BE of $4 \mathrm{mmol} / \mathrm{L}$ estimated from other studies (see "Discussion") during the 5th min after cuff deflation to account for circulating lactate. The values from the total stores model from Table 1 are indicated in Figure $\mathbf{4}$ in relation to the 5 min-integrated stores changes obtained from measured gas exchange (Figure 2). According to the model, during cuff inflation, total $\mathrm{O}_{2} \mathrm{~s}$ did not change and $\mathrm{CO}_{2} \mathrm{~S}$ decreased $164 \mathrm{~mL}$, whereas the 5 min totals (Figure 2) decreased 227 and $497 \mathrm{~mL}$, respectively. The difference indicates that the redistribution of blood volume and flow, the anaerobic work component, and hyperventilation resulted in losses of $227 \mathrm{~mL}$ and $333 \mathrm{~mL}$ in $\mathrm{O}_{2} \mathrm{~S}$ and $\mathrm{CO}_{2} \mathrm{~s}$, respectively. During the 5th min after cuff deflation, $\mathrm{O}_{2} \mathrm{~s}$ increased by $18 \mathrm{~mL}$ and $\mathrm{CO}_{2} \mathrm{~s}$ decreased another $465 \mathrm{~mL}$, whereas the $5 \mathrm{~min}$ totals showed that $\mathrm{O}_{2} \mathrm{~S}$ increased by $518 \mathrm{~mL}$ and $\mathrm{CO}_{2} \mathrm{~S}$ decreased by $1,162 \mathrm{~mL}$. For $\mathrm{O}_{2} \mathrm{~s}$, reducing the $518 \mathrm{~mL}$ gain after cuff deflation by the $18 \mathrm{~mL}$ increase in total stores, as well as the $227 \mathrm{~mL}$ deficit during prior inflation (which is being repaid), leaves a net gain of $273 \mathrm{~mL}$ used to repay the anaerobic cost during ischemia. The $1,162 \mathrm{~mL} 5 \mathrm{~min}$ loss in $\mathrm{CO}_{2} \mathrm{~S}$ after cuff deflation exceeds the $465 \mathrm{~mL}$ loss in absolute stores by $697 \mathrm{~mL}$ (Figure 4). Over the total $10 \mathrm{~min}, 5 \mathrm{~min}$ before and $5 \mathrm{~min}$ after inflation, the ratio of the total loss in $\mathrm{CO}_{2} \mathrm{~S}$ versus gain in $\mathrm{O}_{2} \mathrm{~S}$ is $3.7(1,030 /$ 273), which includes the hyperventilation "artifact" during ischemia.

Table 1.

Estimated oxygen stores $\left(\mathrm{O}_{2} \mathrm{~s}\right)$ and carbon dioxide stores $\left(\mathrm{CO}_{2} \mathrm{~s}\right)$ (milliliters) during three conditions (A, B, and, C) of 15 min exercise: 5 th min baseline, 5th min of inflation, and 5th min after cuff deflation, respectively.

\begin{tabular}{|c|c|c|c|c|c|}
\hline Condition & Location & $\mathbf{P O}_{2}$ & $\mathbf{O}_{2}$ Stores & $\mathbf{P C O}_{2}$ & $\mathrm{CO}_{2}$ Stores \\
\hline \multirow{3}{*}{$\begin{array}{l}\text { A. 5th Min Baseline } \\
(\mathrm{BE}=-1.8 \mathrm{mmol} / \mathrm{L}, \\
\mathrm{pHa}=7.420, \dot{\mathrm{Q}}=15 \mathrm{~L} / \mathrm{min})\end{array}$} & Arterial & 84.1 & 232 & 33.8 & 479 \\
\hline & Venous & 28.9 & 486 & 45.4 & 2,293 \\
\hline & Lung & 84.1 & 576 & 33.8 & 231 \\
\hline Total & - & - & 1,331 & - & 6,827 \\
\hline \multirow{3}{*}{$\begin{array}{l}\text { B. 5th Min Cuff Inflation } \\
(\mathrm{BE}=-1.8 \mathrm{mmol} / \mathrm{L}, \\
\mathrm{pHa}=7.462, \dot{\mathrm{Q}}=14 \mathrm{~L} / \mathrm{min})\end{array}$} & Arterial & 92.1 & 293 & 28.9 & 559 \\
\hline & Tissue & 25.3 & 32 & 44.7 & 3,760 \\
\hline & Lung & 92.1 & 631 & 28.9 & 198 \\
\hline Total & - & - & 1,331 & - & 6,663 \\
\hline$\overline{\mathbf{B}-\mathbf{A}}$ & - & - & $\mathbf{0}$ & - & -164 \\
\hline $\begin{array}{l}\text { C. 5th Min Cuff Deflation* } \\
(\mathrm{BE}=-5.8 \mathrm{mmol} / \mathrm{L} \\
\mathrm{pHa}=7.370, \dot{\mathrm{Q}}=15 \mathrm{~L} / \mathrm{min})\end{array}$ & Arterial & 86.6 & 232 & 31.4 & 402 \\
\hline Total & - & - & 1,349 & - & 6,198 \\
\hline $\bar{C}-\mathbf{B}$ & - & - & 18 & - & -465 \\
\hline$C-A$ & - & - & 18 & - & -629 \\
\hline \multicolumn{6}{|c|}{$\begin{array}{l}\text { Note: } \mathrm{O}_{2} \mathrm{~S} \text { and } \mathrm{CO}_{2} \mathrm{~S} \text { are based on model given in "Methods" of main text with assumptions: } \\
\text { - Total blood volume }=5,900 \mathrm{~mL} \text {. } \\
\text { - Venous volume }=\text { total } \times 0.8=4,720 \mathrm{~mL} \text {; arterial }=\text { total } \times 0.2=1,180 \mathrm{~mL} \text { in conditions } \mathrm{A} \text { and } \mathrm{C} \text {. } \\
\text { - } 300 \mathrm{~mL} \text { was shifted from venous to arterial compartment in condition } \mathrm{B} \text {; i.e., venous }=4,420 \mathrm{~mL} \text { and arterial }=1,480 \mathrm{~mL} \text {. } \\
\text { *Adjusted for } \Delta \mathrm{BE}=-4.0 \mathrm{mmol} / \mathrm{L} \text {. } \\
\mathrm{BE}=\text { base excess (measure of whole blood buffer base), } \mathrm{pHa}=\text { arterial } \mathrm{pH} \text { (negative log of } \mathrm{H}^{+} \text {in arterial blood), } \mathrm{PCO}_{2}=\text { partial pressure of carbon dioxide, } \mathrm{PO}_{2}=\text { par- } \\
\text { tial pressure of oxygen, } \mathrm{Q}=\text { cardiac output. }\end{array}$} \\
\hline
\end{tabular}




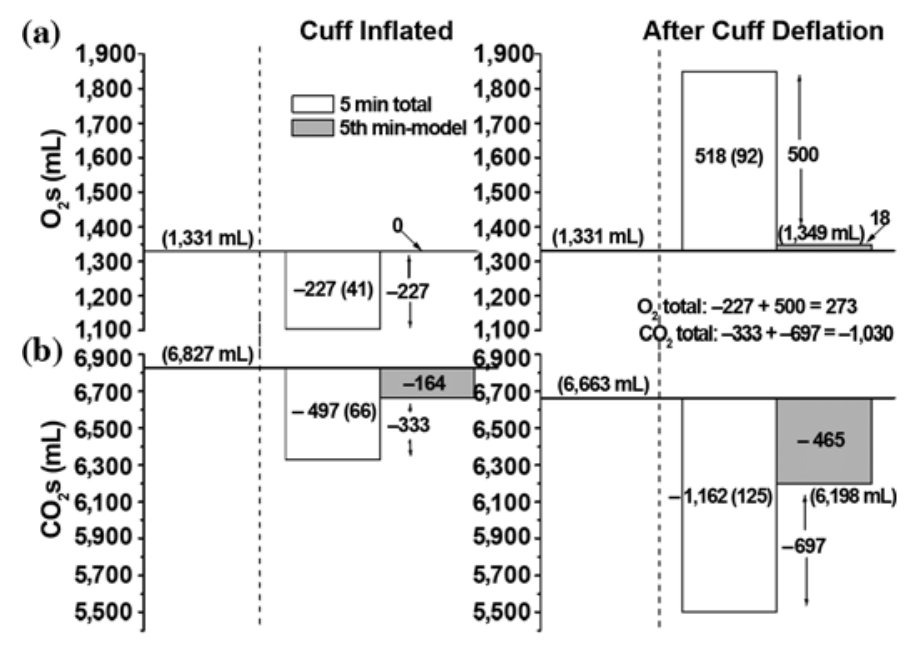

Figure 4.

Values for total gas stores from model in Table $\mathbf{1}$ in relation to changes in gas stores from time-integrated $\dot{\mathrm{V}}_{2}$ and $\dot{\mathrm{V}} \mathrm{CO}_{2}$ shown in Figure 2. Standard error of the mean is shown for latter in parentheses. Total increase in (a) $\mathrm{O}_{2} \mathrm{~s}$ for 5 min of inflation and 5 min postinflation phase is $273 \mathrm{~mL}$, and decrease in (b) $\mathrm{CO}_{2} \mathrm{~S}$ is $1,030 \mathrm{~mL}$. $\mathrm{CO}_{2}=$ carbon dioxide, $\mathrm{CO}_{2} \mathrm{~s}=\mathrm{CO}_{2}$ stores, $\mathrm{O}_{2}=$ oxygen, $\mathrm{O}_{2} \mathrm{~s}=\mathrm{O}_{2}$ stores, $\dot{\mathrm{V}} \mathrm{CO}_{2}=\mathrm{CO}_{2}$ output, $\dot{\mathrm{VO}}_{2}=\mathrm{O}_{2}$ uptake.

\section{DISCUSSION}

The initial increase in $\dot{\mathrm{VO}}_{2}$ during the 1 st min of ischemia can be accounted for by the bolus of venous blood from the legs moving into the central circulation during cuff inflation and its oxygenation to arterial blood as it traverses the pulmonary capillaries. This $\approx 30 \mathrm{~mL}$ of $\mathrm{O}_{2}$ (Figure 2) would reoxygenate $300 \mathrm{~mL}$ of venous blood having an $\mathrm{O}_{2}$ content of 10 vol\%. This rise in $\dot{\mathrm{VO}}_{2}$ and the $\approx 30 \mathrm{~mL}$ significant simultaneous loss of $\mathrm{CO}_{2}(p=0.004)$ indicated a $300 \mathrm{~mL}$ shift of blood from the venous to arterial compartment. A redistribution of blood flow accounted for the transient reduction in $\dot{\mathrm{VO}}_{2}$ during the 2nd min of ischemia, whereby cuffs restricted $\mathrm{O}_{2}$ delivery to the legs by arterial blood, reducing $\dot{\mathrm{V}}_{2}$ temporarily and increasing $\mathrm{O}_{2}$ content of mixed venous blood. Similar cardiovascular readjustments with breath holds during exercise have been noted to reduce $\dot{\mathrm{VO}}_{2}$ [26]. The linear rise during the last $3 \mathrm{~min}$ with ischemia reflects the decreasing mechanical efficiency and the progressive partial restoration of leg circulation. The peak $45 \mathrm{~s}$ after cuff deflation signifies lung reoxygenation of venous blood returning from the legs, extracting more $\mathrm{O}_{2}$ to repay the aerobic and anaerobic deficit incurred during the prior ischemia. Most of the anaerobic deficit was repaid over the last 3 min of uncuffed exercise as $\dot{\mathrm{V}}_{2}$ returned to near baseline exercise levels. However, some residual debt repayment probably occurred during the postexercise rest because the repayment exceeded the deficit at the start of exercise by $423 \mathrm{~mL}$ (Figure 1) and the half-time of the off-response (37 s) was significantly ( $p=0.001)$ slower than the onresponse (27 s); the latter value agreed with previous reports [27-28].

The estimated $\mathrm{CO}_{2}$ capacitance value of $1.2 \mathrm{~L} \cdot \mathrm{mmHg}^{-1}$ $\cdot \mathrm{kg}^{-1}$ is lower than that (1.6) interpolated for the same exercise workload from a report [29] during $15 \mathrm{~min}$ of hyperventilation, although values twice as high have also been reported [30]. Capacitance values are directly related to the length of experiments, because more $\mathrm{CO}_{2}$ is then washed out of slower compartments [31]. Because leg perfusion was impaired during our experiments, one would have expected a relatively low capacitance value because $\mathrm{CO}_{2}$ in blood and tissue of the legs are then washed out at a slower rate, being somewhat isolated from the lung. Another consideration is that $\mathrm{CO}_{2} \mathrm{~S}$ change significantly slower than $\mathrm{O}_{2} \mathrm{~s}$, having a half-time of 4.0 min versus 0.5 min for $\mathrm{O}_{2} \mathrm{~s}$, based on studies on dogs by Farhi and Rahn [24]. This finding suggests that part of the loss in $\mathrm{CO}_{2} \mathrm{~S}$ following cuff deflation may be attributed to the hyperventilation during the prior ischemia.

After cuff deflation, the larger $\mathrm{CO}_{2} \mathrm{~S}$ loss relative to $\mathrm{O}_{2} \mathrm{~S}$ gain resulted from the $\mathrm{HCO}_{3}{ }^{-}$buffering of lactate entering the circulation. Correlation of lactate levels with excess $\dot{\mathrm{V} C O}{ }_{2}$ in relation to $\dot{\mathrm{VO}}_{2}$ during and after heavy exercise resulted in the "anaerobic threshold" concept [32-33]. Excess $\dot{\mathrm{V}} \mathrm{CO}_{2}$ during exercise has also been used to estimate lactate accumulation in physically fit subjects [34] and cardiac patients [35]. The elevated $\dot{\mathrm{V}} \mathrm{CO}_{2}$ and $\mathrm{CO}_{2} \mathrm{~S}$ depletion is caused by carbonic acid, arising from the combination of $\mathrm{H}^{+}$with $\mathrm{HCO}_{3}{ }^{-}$; dissolved $\mathrm{CO}_{2}$ from the muscle tissue being transported to the lungs once circulation is restored; and elevated $\dot{\mathrm{V}}_{\mathrm{E}}$. As shown by $\dot{\mathrm{V}}_{\mathrm{E}} / \dot{\mathrm{V}}_{\mathrm{CO}}$ in Figure 3, the metaboreflex ventilatory drive was quickly diminished after cuff deflation, but the drive was then taken over by the chemoreflex stimulated by elevated $\mathrm{H}^{+}$and $\mathrm{PCO}_{2}$ in blood arriving at central chemoreceptors and continuing during subsequent rest.

In studies somewhat similar to this one, a rise of arterial blood lactate of $\approx 4 \mathrm{mmol} / \mathrm{L}$ was reported 4 to $5 \mathrm{~min}$ after cuff deflation [36] and also a $4 \mathrm{mmol} / \mathrm{L}$ loss of plasma $\mathrm{HCO}_{3}{ }^{-}$[37]. This amount of lactate release was incorporated into the model shown in Table 1 and Figure 4. If $4 \mathrm{mmol} / \mathrm{L}$ of lactate release from the legs to central 
circulation was entirely buffered by $\mathrm{HCO}_{3}{ }^{-}$during the 5 min postinflation period, it would amount to a $\mathrm{CO}_{2} \mathrm{~S}$ loss of $4 \mathrm{mmol} / \mathrm{L} \times 5.9 \mathrm{~L} \times 22.3 \mathrm{~mL} / \mathrm{mmol}=526 \mathrm{~mL}$ [33]. This amount accounts for 75 percent of the $697 \mathrm{~mL}$ estimate. However, the ratio of $\mathrm{CO}_{2}$ loss to $\mathrm{O}_{2}$ gain of 2.6 (697/273) suggests that a part of the lactate may have been converted by oxidation, in addition to being buffered [38]. These and other biochemical processes must have continued beyond the postexercise resting measurement period to fully restore $\mathrm{O}_{2} \mathrm{~S}$ and $\mathrm{CO}_{2} \mathrm{~s}$ to baseline levels of 1,331 and 6,827 mL, respectively. However, most of the excess $\mathrm{CO}_{2}$ was eliminated by the time exercise stopped because $\mathrm{VCO}_{2}$ had returned to baseline (Figure 1). Without prolonged lactate turnover measurements, we can only generalize that the majority of the lactate was buffered in preference to other chemical pathways to account for the $\mathrm{CO}_{2} \mathrm{~s}$ loss exceeding the $\mathrm{O}_{2} \mathrm{~S}$ gain. Qualitatively, $\dot{\mathrm{V}}_{\mathrm{E}}$ increases during exercise with cuffs inflated, depleting $\mathrm{CO}_{2} \mathrm{~s}$, while the partially anaerobic exercise continues. When cuffs are deflated and after exercise stops, metabolic by-products from the legs returning to the central circulation keep ventilation elevated to repay $\mathrm{O}_{2} \mathrm{~S}$, while $\mathrm{CO}_{2} \mathrm{~S}$ remains below baseline for a longer time.

Clearly, the assumptions in the total gas stores model demonstrated in Table 1 and Figure 4 will affect the absolute values and changes in gas store values. Some quantities, such as tissue water and arterial and venous blood volumes, are not easily measured and were taken from estimates in the literature. To quantify the effect of variations in these assumed values, in Table 2, we show changes in total $\mathrm{O}_{2} \mathrm{~S}$ and $\mathrm{CO}_{2} \mathrm{~S}$ resulting from variations in values from those used in Table 1 during the three exercise conditions. We varied indicated values for relevant physiological components individually, assuming the other variables remained constant. Table 2 indicates that calculations of total $\mathrm{O}_{2} \mathrm{~S}$ and $\mathrm{CO}_{2} \mathrm{~S}$ and phase differences in stores are most sensitive to values for $\mathrm{Hb}$ and reductions in $\dot{Q}$ during the ischemic phase. Any alveolar-arterial differences in $\mathrm{PO}_{2}$ and $\mathrm{PCO}_{2}$ greatly influence total stores, especially $\mathrm{CO}_{2} \mathrm{~s}$, but the effect on store differences is smaller, somewhat similar to changing values for the other components. Therefore, performing invasive measurements, including arterial and mixed venous blood gases and lactate, in more definitive future studies is important.

Most studies using cuffs to induce acute exercise ischemia have focused on the $\dot{\mathrm{V}}_{\mathrm{E}}$ response following cuff deflation to study $\mathrm{CO}_{2}$ chemoreceptor response mechanisms. Data from some of these reports [23,36-37,39-40] allowed a gas store pattern estimation to compare with this study and are shown in Table 3. Generalizations from these limited data include (1) an inverse relationship between cuff pressure and $\mathrm{O}_{2} \mathrm{~s}$ reduction during inflation, (2) a direct relationship between workload and the increase in $\mathrm{O}_{2} \mathrm{~S}$ and reduction in $\mathrm{CO}_{2} \mathrm{~S}$ after cuff deflation, and (3) the $\mathrm{CO}_{2} \mathrm{~s}$ loss after cuff deflation exceeds the change during inflation and also exceeds the $\mathrm{O}_{2}$ s gain in recovery. From the time trends in the present study and those prior studies where time resolution was presented [37,39], apparently during inflation, the decrease in $\mathrm{O}_{2} \mathrm{~S}$ is attenuated as exercise duration increases. This finding is probably associated with the increasing $\dot{\mathrm{VO}}_{2}$ required by the

Table 2.

Effect on total gas stores of variations in assumed values for gas stores model during three conditions A, B, and C of 15 min exercise: 5 th min baseline, 5th min of cuff inflation, and 5th min after cuff deflation, respectively.

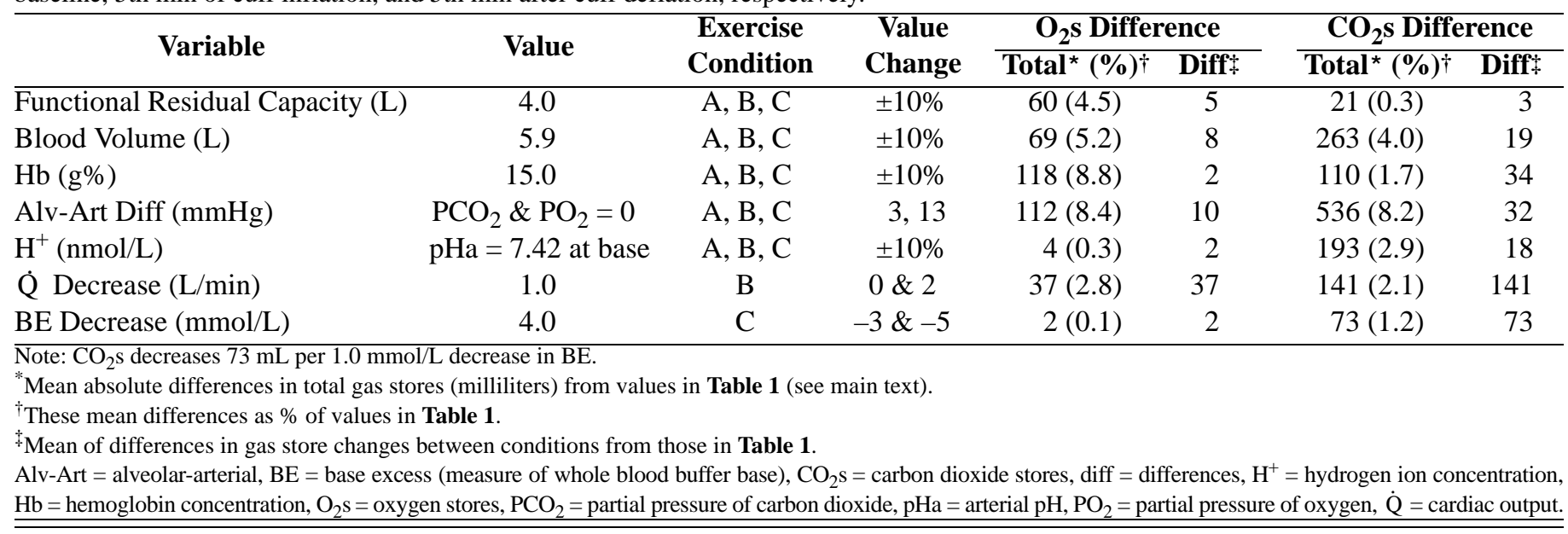


Table 3.

Cumulative time-integrated oxygen uptake $\left(\dot{\mathrm{V}}_{2}\right)$, carbon dioxide output $\left(\dot{\mathrm{V}}_{\mathrm{CO}}\right)$, and pulmonary ventilation $\left(\dot{\mathrm{V}}_{\mathrm{E}}\right)$ differences from baseline during leg cuff inflation and after cuff deflation.

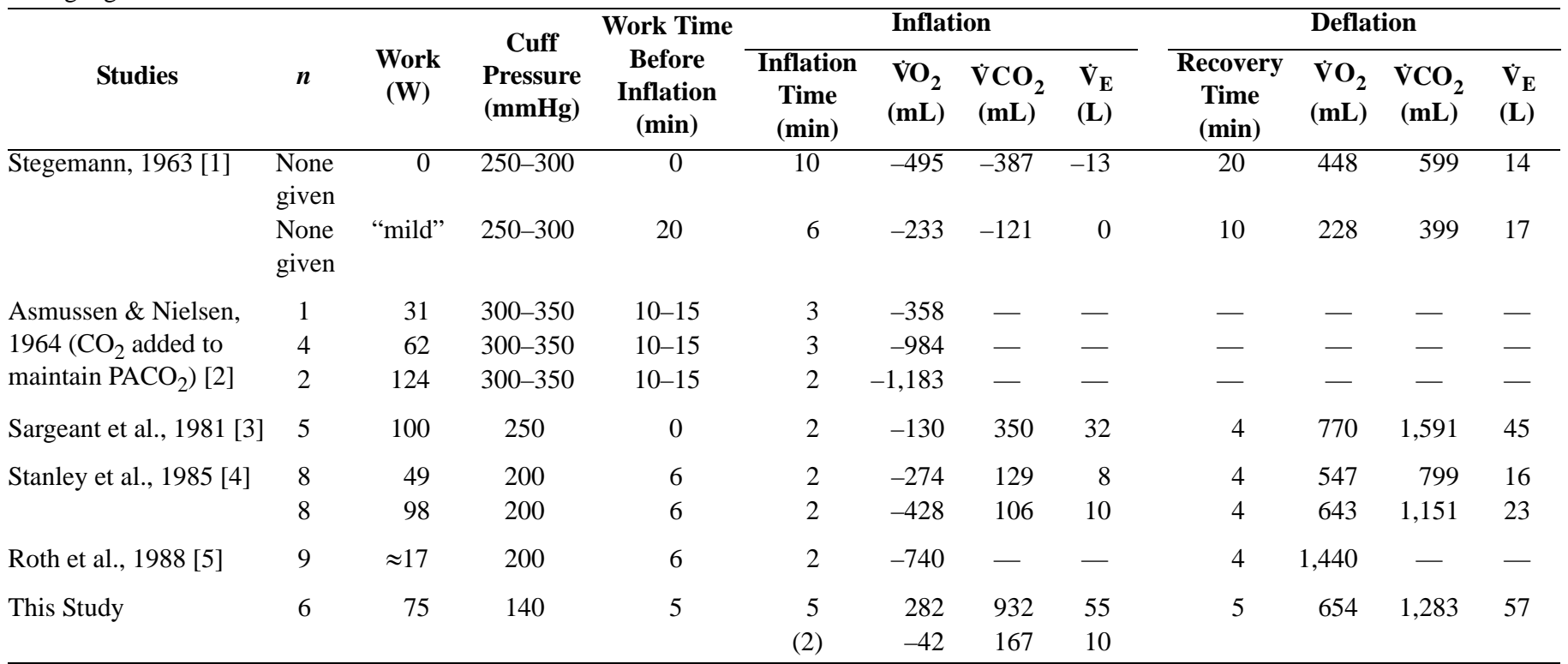

Note: See legend to Figure 2 for "predicted" values for $\dot{\mathrm{VO}}_{2}$ and $\dot{\mathrm{V}} \mathrm{CO}_{2}$ for this study; here all "predicted" values were assumed equal to baseline.

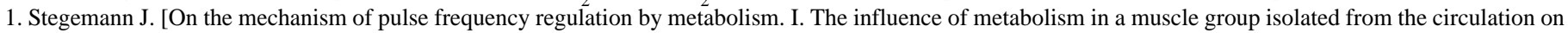
the behavior of the pulse frequency]. Pflügers Arch Gesamte Physiol Menschen Tiere. 1963;276:481-92. German. [PMID: 13983630]

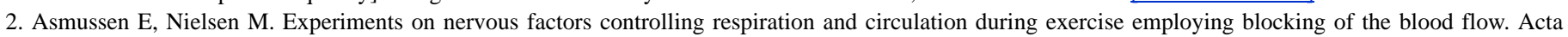
Physiol Scand. 1964;60:103-11. [PMID: 14131818]

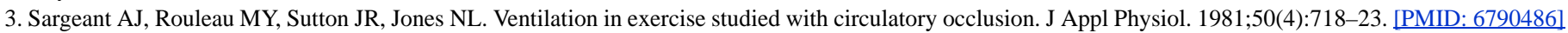

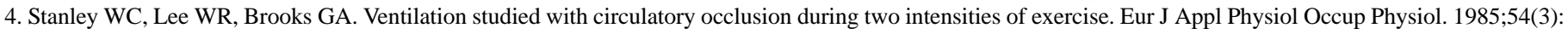
269-77. [PMID: 3933976]

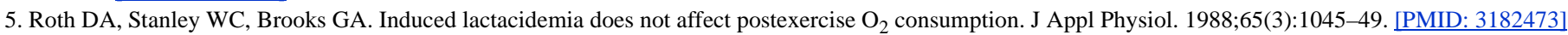
$\mathrm{CO}_{2}=$ carbon dioxide, $\mathrm{PACO}_{2}=$ partial pressure of alveolar $\mathrm{CO}_{2}(\mathrm{mmHg})$.

elevated $\dot{V}_{\mathrm{E}}$ and extra muscular effort and partial restoration of leg blood flow that diminish the $\mathrm{O}_{2} \mathrm{~S}$ deficit and increase the $\mathrm{CO}_{2} \mathrm{~S}$ deficit. Apparently, leg cuff pressures must be $>90 \mathrm{mmHg}$ during exercise to affect measured $\dot{\mathrm{V}} \mathrm{CO}_{2}$ and $\dot{\mathrm{VO}}_{2}$ during exercise [41-42].

\section{SUMMARY AND CONCLUSIONS}

The events in these experiments can be described as a respiratory alkalosis during ischemia, followed by a metabolic acidosis after cuff deflation when metabolites from the anaerobic portion of leg work return to the central circulation. Changes in $\mathrm{O}_{2} \mathrm{~S}$ depend mainly on perfusion through lung and tissue, while $\mathrm{CO}_{2} \mathrm{~s}$ changes are primarily determined by $\dot{\mathrm{V}}_{\mathrm{E}}$, venous blood redistribution, and $\mathrm{HCO}_{3}{ }^{-}$buffering of lactate. This study estimated that the ischemia required a repayment of $273 \mathrm{~mL}$ of $\mathrm{O}_{2}$ and produced $697 \mathrm{~mL}$ of $\mathrm{CO}_{2}$. These values depend on workload, work duration with ischemia, the cuff pressure determining the perfusion impairment, and the intensity of the metaboreflex. The amount of anaerobic debt incurred and tolerated and the recovery from a given ischemic exercise scenario will depend on the aerobic fitness of the subject and related blood pressure reflex response. These factors must be considered if this form of exercise is further evaluated and implemented for rehabilitation.

\section{ACKNOWLEDGMENTS}

We thank the subjects for their cooperation in making this study possible.

Jack Loeppky is now retired in Cranbrook, British Columbia, Canada.

This material was based on work supported by the Department of Veterans Affairs, Veterans Health Administration, Rehabilitation Research and Development Service, 
grant F4096R to Milton V. Icenogle, MD, Cardiology Section, Veterans Integrated Service Network 18, Albuquerque, New Mexico.

The authors have declared that no competing interests exist.

\section{REFERENCES}

1. Tyni-Lenné R, Dencker K, Gordon A, Jansson E, Sylvén C. Comprehensive local muscle training increases aerobic working capacity and quality of life and decreases neurohormonal activation in patients with chronic heart failure. Eur J Heart Fail. 2001;3(1):47-52. [PMID: 11163735]

2. Eiken O. Responses to dynamic leg exercise in man as influenced by changes in muscle perfusion pressure. Acta Physiol Scand Suppl. 1987;566:1-37. [PMID: 3480686]

3. Sundberg CJ, Kaijser L. Effects of graded restriction of perfusion on circulation and metabolism in the working leg; quantification of a human ischaemia-model. Acta Physiol Scand. 1992;146(1):1-9. [PMID: 1442118]

4. Takarada Y, Sato Y, Ishii N. Effects of resistance exercise combined with vascular occlusion on muscle function in athletes. Eur J Appl Physiol. 2002;86(4):308-14.

[PMID: 11990743]

5. Teramoto M, Golding LA. Low-intensity exercise, vascular occlusion, and muscular adaptations. Res Sports Med. 2006; 14(4):259-71. [PMID: 17214403$]$

6. Takarada Y, Takazawa H, Ishii N. Applications of vascular occlusion diminish disuse atrophy of knee extensor muscles. Med Sci Sports Exerc. 2000;32(12):2035-39. [PMID: 11128848]

7. Burgomaster KA, Moore DR, Schofield LM, Phillips SM, Sale DG, Gibala MJ. Resistance training with vascular occlusion: metabolic adaptations in human muscle. Med Sci Sports Exerc. 2003;35(7):1203-8. [PMID: 12840643]

8. Nygren AT, Sundberg CJ, Göransson H, EsbjörnssonLiljedahl M, Jansson E, Kaijser L. Effects of dynamic ischaemic training on human skeletal muscle dimensions. Eur J Appl Physiol. 2000;82(1-2):137-41. [PMID: 10879455]

9. Piepoli M, Clark AL, Volterrani M, Adamopoulos S, Sleight P, Coats AJ. Contribution of muscle afferents to the hemodynamic, autonomic, and ventilatory responses to exercise in patients with chronic heart failure: effects of physical training. Circulation. 1996;93(5):940-52. [PMID: 8598085]

10. Loeppky JA, Gurney B, Kobayashi Y, Icenogle MV. Effects of ischemic training on leg exercise endurance. J Rehabil Res Dev. 2005;42(4):511-22. [PMID: 16320146]

11. Scott AC, Wensel R, Davos CH, Georgiadou P, Kemp M, Hooper J, Coats AJ, Piepoli MF. Skeletal muscle reflex in heart failure patients: role of hydrogen. Circulation. 2003; 107(2):300-306. [PMID: 12538432]

12. Loeppky JA, Luft UC. Fluctuations in $\mathrm{O}_{2}$ stores and gas exchange with passive changes in posture. J Appl Physiol. 1975;39(1):47-53. [PMID: 1150591]

13. Chuang ML, Ting H, Otsuka T, Sun XG, Chiu FY, Beaver WL, Hansen JE, Lewis DA, Wasserman K. Aerobically generated $\mathrm{CO}(2)$ stored during early exercise. J Appl Physiol. 1999;87(3):1048-58. [PMID: 10484576]

14. Baldwin KM. Comments on classical papers. J Appl Physiol. 2005;99(4):1241-42. [PMID: 16160016]

15. Luft UC, Loeppky JA, Mostyn EM. Mean alveolar gases and alveolar-arterial gradients in pulmonary patients. J Appl Physiol. 1979;46(3):534-40. [PMID: 438024]

16. Rahn H, Fenn WO. A graphical analysis of the respiratory gas exchange: The $\mathrm{O}_{2}-\mathrm{CO}_{2}$ diagram. Washington (DC): American Physiological Society; 1955. p. 40.

17. McGregor M, Becklake MR. The relationship of oxygen cost of breathing to respiratory mechanical work and respiratory force. J Clin Invest. 1961;40:971-80. [PMID: 13773979]

18. Vella CA, Marks D. Robergs RA. Oxygen cost of ventilation during incremental exercise to $\mathrm{VO}_{2}$ max. Respirology. 2006;11(2):175-81. [PMID: 16548903]

19. Vidal Melo MF, Loeppky JA, Caprihan A, Luft UC. Alveolar ventilation to perfusion heterogeneity and diffusion impairment in a mathematical model of gas exchange. Comput Biomed Res. 1993;26(2):103-20. [PMID: 8477584]

20. Loeppky JA, Caprihan A, Altobelli SA, Icenogle MV, Scotto P, Vidal Melo MF. Validation of a two-compartment model of ventilation/perfusion distribution. Respir Physiol Neurobiol. 2006;151(1):74-92. [PMID: 16024300]

21. Severinghaus JW. Simple, accurate equations for human blood $\mathrm{O}_{2}$ dissociation computations. J Appl Physiol. 1979; 46(3):599-602. [PMID: 35496]

22. Loeppky JA, Fletcher ER, Roach RC, Luft UC. Relationship between whole blood base excess and $\mathrm{CO}_{2}$ content in vivo. Respir Physiol. 1993;94(1):109-20. [PMID: 8272578]

23. Asmussen E, Nielsen M. Experiments on nervous factors controlling respiration and circulation during exercise employing blocking of the blood flow. Acta Physiol Scand. 1964;60: 103-11. [PMID: 14131818]

24. Farhi LE, Rahn H. Gas stores of the body and the unsteady state. J Appl Physiol. 1955;7(5):472-84. [PMID: 14367232]

25. Loeppky JA, Luft UC, Fletcher ER. Quantitative description of whole blood $\mathrm{CO}_{2}$ dissociation curve and Haldane effect. Respir Physiol. 1983;51(2):167-81. [PMID: 6405469]

26. Lindholm P, Linnarsson D. Pulmonary gas exchange during apnoea in exercising men. Eur J Appl Physiol. 2002; 86(6):487-91. [PMID: 11944095]

27. Linnarsson D. Dynamics of pulmonary gas exchange and heart rate changes at start and end of exercise. Acta Physiol Scand Suppl. 1974;415:1-68. [PMID: 4621315] 
28. Özyener F, Rossiter HB, Ward SA, Whipp BJ. Influence of exercise intensity on the on- and off-transient kinetics of pulmonary oxygen uptake in humans. J Physiol. 2001; 533(Pt 3):891-902. [PMID: 11410644]

29. Jones NL, Jurkowski JE. Body carbon dioxide storage capacity in exercise. J Appl Physiol. 1979;46(4):811-15. [PMID: 457560]

30. Ozcelik O, Ward SA, Whipp BJ. Effect of altered body $\mathrm{CO}_{2}$ stores on pulmonary gas exchange dynamics during incremental exercise in humans. Exp Physiol. 1999;84(5): 999-1011. [PMID: 10502667$]$

31. Farhi LE. Gas stores of the body. In: Fenn WO, Rahn H, editors. Handbook of physiology. Section 3: Respiration. Vol I. Washington (DC): American Physiological Society; 1964. p. 873-85.

32. Stringer W, Wasserman K, Casaburi R. The $\mathrm{VCO}_{2} / \mathrm{VO}_{2}$ relationship during heavy, constant work rate exercise reflects the rate of lactic acid accumulation. Eur J Physiol Occup Physiol. 1995;72(1-2):25-31. [PMID: 8789566]

33. Whipp BJ, Mahler M. Dynamics of pulmonary gas exchange. In: West JB, editor. Pulmonary gas exchange. New York (NY): Academic Press; 1980. p. 33-96.

34. Hirakoba K, Maruyama A, Misaka K. Prediction of blood lactate accumulation from excess $\mathrm{CO}_{2}$ output during constant exercise. Appl Human Sci. 1996;15(5):205-10. [PMID: 8979401]

35. Wilson JR, Ferraro N, Weber KT. Respiratory gas analysis during exercise as a noninvasive measure of lactate concentration in chronic congestive heart failure. Am J Cardiol. 1983;51(10):1639-43. [PMID: 6407294]

36. Roth DA, Stanley WC, Brooks GA. Induced lactacidemia does not affect postexercise $\mathrm{O}_{2}$ consumption. J Appl Physiol. 1988;65(3):1045-49. [PMID: 3182473$]$
37. Sargeant AJ, Rouleau MY, Sutton JR, Jones NL. Ventilation in exercise studied with circulatory occlusion. J Appl Physiol. 1981;50(4):718-23. [PMID: 6790486]

38. Kelley KM, Hamann JJ, Navarre C, Gladden LB. Lactate metabolism in resting and contracting canine skeletal muscle with elevated lactate concentration. J Appl Physiol. 2002; 93(3):865-72. [PMID: 12183479]

39. Stanley WC, Lee WR, Brooks GA. Ventilation studied with circulatory occlusion during two intensities of exercise. Eur J Appl Physiol Occup Physiol. 1985;54(3):269-77. [PMID: 3933976$]$

40. Stegemann J. [On the mechanism of pulse frequency regulation by metabolism. I. The influence of metabolism in a muscle group isolated from the circulation on the behavior of the pulse frequency]. Pflügers Arch Gesamte Physiol Menschen Tiere. 1963;276:481-92. German.

[PMID: 13983630]

41. Greiner A, Esterhammer R, Pilav S, Arnold W, Santner W, Neuhauser B, Fraedrich G, Jaschke WR, Schocke MF. High-energy phosphate metabolism in the calf muscle during moderate isotonic exercise under different degrees of cuff pressure: a phosphorus 31 magnetic resonance spectroscopy study. J Vasc Surg. 2005;42(2):259-67.

[PMID: 16102624]

42. Smith SA, Gallagher KM, Norton KH, Querry RG, WelchO'Connor RM, Raven PB. Ventilatory responses to dynamic exercise elicited by intramuscular sensors. Med Sci Sports Exerc. 1999;31(2):277-86. [PMID: 10063818$]$

Submitted for publication November 28, 2007. Accepted in revised form March 26, 2008. 